УДК 780.647.2

DOI 22185186.2019.1.21

Анастасія Свтушенко

\title{
ДЕЯКІ АСПЕКТИ ШКОЛОТВОРЧОЇ ФУНКЦЇ̈ БАЯННО-АКОРДЕОННОГО МИСТЕЦТВА
}

Українське музичне мистецтво є цілісним національно самобутнім феноменом, складовими якого є традиційна (аутентична) культура й академічна сфера (композиторська творчість, виконавство і професійна освіта). Процес його формування тісно пов'язаний з історичними та соціокультурними передумовами, які увібрали традиції вітчизняної та західноєвропейської музичних культур. 3 цієї точки зору значний інтерес викликає баянно-акордеонне мистецтво в Україні, в якому віддзеркалено музично-історичні тенденції розвитку як академічного народно-інструментального виконавства загалом, так і баянно-акордеонного мистецтва для дітей і юнацтва зокрема.

Баян і акордеон у музичному мистецтві XXI століття - це концертні академічні інструменти з широкими тембровими, технічними можливостями. Українське професійне баянно-акордеонне виконавське мистецтво упродовж півстолітнього періоду своєї історії пройшло складний шлях розвитку, оскільки у цей час функція баяна й акордеона трансформувалась від акомпонуючого інструмента до концертного й академічного.

Мета статті - висвітлити деякі аспекти школотворчої функції баянно-акордеонного мистецтва та проаналізувати іiі вплив на розвиток сучасного баянно-акордеонного мистецтва.

Поштовхом для створення професійного баянного мистецтва стало аматорське музикування, але подальший його розвиток відбувався в середині XX ст. У цей час відкрилися перші відділення народних інструментів із класами баяна в початковій і середній ланках системи музичної освіти. Відбулося осмислення комунікаційної функції баяна як сольного інструмента, нерозривно пов'язаної з розповсюдженням у концертній практиці готово-виборного інструмента. Відкриття класу баяна в музичних школах спонукало до пошуку та винайдення нових конструкцій баянного асортименту з урахуванням фізичних особливостей дітей підліткового віку. Цьому сприяло виготовлення якісних інструментів у Києві, Харкові, Житомирі, Горлівці, Кременному.

(C) Анастасія Свтушенко, 2019 208 
Напівпрофесійна стадія пов'язана з розвитком баянно-акордеонного мистецтва в умовах сільського і міського типів культури 3 першої половини XIX ст. до 20-30-их років XX ст. Пріоритетного поширення набула гармонь завдяки своїй простій конструкції, у той час як баян - більш складний інструмент - увійшов у музичний побут пізніше. Слід нагадати, що в Свропі баян називають «акордеоном», а хроматична гармоніка у нас носить назву «баян». Так, дослідники вказують на диференціацію готових баянів, «...у яких акомпанемент у лівій руці подається у вигляді штампованих, нерухомо встановлених акордів: мажорних, мінорних тризвуків та септакордів, і виборних, у яких клавіатура аналогічна правій руці» [2, с. 51-56].

Природно, що відбулося переосмислення музично-технічних характеристик, способів звукоутворення і вдосконалення виконавського потенціалу баяністів. Тому не випадково дослідники зазначають, що «...у баянному мистецтві отримують широке застосування нові, специфічноінструментальні прийоми гри, що увиразнюють інтонаційне оновлення музично-виразових засобів XX ст., яке безпосередньо спостерігається в оригінальному баянному репертуарі, в тому числі для дітей. [1, с. 58].

Рішенню художніх і технічних завдань для баяніста сприяли також різні методичні посібники: «Теоретичні основи визначення об'єктивного музичного руху» А. Семешка (1993), «Питання формування виконавської майстерності в процесі навчання гри на баяні» О. Паньківа (1995), «Теоретичні основи формування виконавської майстерності баяніста» М. Давидова (1997), «Гармоніки, баяни, акордеони. Духовні матеріали та матеріальні функціонування в музичній культурі України XIX-XX століть» С. Іванова (2002), «Нариси з історії української музики для баяна» А. Сташевського (2006).

Примітно, що у 50-60-ті роки XX століття вагомий внесок до баянного репертуару зробили композитори, які самі не володіли цим інструментом, але відчували його необмежені можливості: Ю. Шамо, В. Підвала, Г. Ляшенко, Ю. Іщенко, О. Пушкаренко.

Велику роль у процесі становлення баянної школи відіграла діяльність видатних вітчизняних музикантів - баяністів-акордеоністів різних поколінь М. Різоля, С. Грінченка, К. М'яскова, В. Подгорного, В. Безфамільнова, А. Семешка, В. Рунчака, О. Міщенка, І. Снєдкова, В. Губанова та педагогів М. Оберюхтіна, М. Давидова, І. Яшкевича, О. Назаренка.

Слід зазначити, що сьогодні в українській музичній культурі також вагоме місце посідає саме акордеонне мистецтво, відокремлене значною мірою від баянного. Свідченням цього є високий рівень виконавської майстерності 
вітчизняних акордеоністів, активізація композиторської творчості для акордеона, використання інструмента у різних сферах музичної практики.

Однак процес утвердження акордеона на українській концертній естраді був досить складним і неоднозначним. Цей інструмент лише декілька десятиліть тому став надбанням академічно-професійної сфери музичного мистецтва. Тривалий час спостерігалася фахова залежність акордеона від фортепіано і баяна. Тому досить актуальним і сьогодні залишається питання формування оригінальної методики викладання гри саме на акордеоні.

Різним аспектам, які стосуються виховання музиканта-інструменталіста у сфері акордеонного мистецтва, присвячені праці Е. Борисенка, В. Власова, М. Давидова, В. Дорохіна, В. Князєва, А. Мірека, О. Показаннік, В. Салія, О. Спешилової, А. Іванова, А. Ілюхіна, П. Гвоздева, М. Отделенова, О. Кудрявцева та ін. Водночас, попри значущість праць українських і зарубіжних учених, у більшості з них проблеми методики акордеоністів розглядаються у світлі методики викладання гри на баяні, без урахування специфіки акордеона.

Сформувалася методика викладання гри на акордеоні, яка базувалася переважно на основі фортепіанної та баянної методик. Варто відзначити, що на початку і в середині XX ст. піаністи дуже широко використовували викладання гри на акордеоні. Застосування методики баяністів зумовлене однотипністю лівої клавіатури акордеона і баяна, способами звуковидобування, прийомами ведення міха, штрихами. Крім цього, методика баяністів почала формуватися значно раніше, ще у 20-30-х рр. XX ст., коли у Київському музичному технікумі, а згодом у Київській консерваторії почали готувати виконавців на народних інструментах, зокрема баяністів. Кафедру народних інструментів Київської консерваторії очолив видатний музикант і педагог М. Геліс. Митець, використовуючи надбання методик, які склалися раніше в суміжних сферах музичного виконавства, створив методику викладання гри на народних інструментах. На той час система освіти баяністів уже охоплювала всі три рівні: початковий (школу), середній (технікум), вищий навчальний заклад (консерваторію) та була розроблена методика і теорія баянного виконавства. В акордеонному мистецтві таких процесів не відбувалося ще декілька десятиліть, однак воно завжди тяжіло до баянного. Це виявилося у використанні акордеоністами здобутків баяністів у сфері звукоутворення i звуковидобування, але варто зауважити, що питання, які стосуються постановки правої руки, аплікатурних принципів, особливостей виконання різних фактур, потребують урахування специфіки акордеона. 
Із розвитком методики викладання гри на акордеоні відбувся розподіл посібників («Школа гри» і «Самовчитель»). «Школа гри» була спрямована на навчання під керівництвом педагога, а «Самовчитель» використовувався для самостійного оволодіння інструментом. Цей поділ пов'язаний із розмежуванням сфер використання акордеона і різними завданнями, які ставилися перед акордеоністами в навчальних закладах і у сфері аматорського музикування. У 1960-1970-х рр. 3'явилася ціла низка навчально-методичних посібників А. Мірека, Г. Наумова, П. Лондонова, В. Лушнікова, Г. Салова та ін. Ці видання були досить актуальними i прогресивними, грунтувалися на досягненнях тогочасної музичної педагогіки з урахуванням специфіки акордеоністів [7].

Однак варто зауважити, що у згаданий період освіта і методика викладання гри на акордеоні були спрямовані на сфери домашнього музикування і художньої самодіяльності. Функції акордеона обмежували виконанням масової народної, естрадної, танцювальної музики, недооцінювалися віртуозно-технічні ресурси інструмента, безперспективним вважалося використання акордеона у професійно-академічній сфері музичного мистецтва.

У 1990-х рр. в освіті акордеоністів відбулися позитивні зміни - у мистецьких закладах вищої освіти України було відкрито класи акордеона і з'явилася спеціалізація «акордеоніст». Акордеонне мистецтво вийшло із затінку інших суміжних спеціальностей у самостійну музично-педагогічну галузь. Таким чином була сформована українська акордеонна школа в сукупності їі регіональних відгалужень. Лідером у формуванні національної акордеонної школи була кафедра народних інструментів Національної музичної академії України імені П. І. Чайковського, яку очолював професор М. Давидов. Митець на основі власного багаторічного педагогічного досвіду створив теорію виконавської майстерності баяніста (акордеоніста), яка знайшла відображення у праці «Теоретичні основи формування виконавської майстерності баяніста (акордеоніста)» [1]. Ця робота не має аналогів в українській та зарубіжній навчально-методичній літературі та є надзвичайно значущою для подальшого розвитку музичної педагогіки.

3 ініціативи М. Давидова у 1990 р. на кафедрі народних інструментів Національної музичної академії України імені П. І. Чайковського було відкрито спеціальний клас акордеона, який очолила випускниця класу професора Є. Черказова. У 1995 р. Є. Черказова розробила першу навчальну програму по класу акордеона для вищих музичних навчальних закладів України. Програма грунтується на двох основних принципах: створення 
репертуару, максимально адаптованого під діапазон, темброві та фактурні можливості акордеона; удосконалення виконавської майстерності молодих музикантів під керівництвом педагога-акордеоніста [4].

Навчальна програма по класу акордеона реалізується шляхом застосування конкретної методики організації навчання і творчості, до якої належать художньо-змістовий і раціонально-технічний компоненти. Художньо-змістовий компонент методики навчання акордеоністів спрямований на розвиток художньої уяви й асоціативного мислення студентів, що сприяє осягненню змісту і створенню цілісної художньої концепції музичного твору. Раціонально-технічний компонент методики спрямований на розвиток простих і складних прийомів виконавської техніки. Розроблені підходи щодо підбору навчального репертуару акордеоністів, до якого входять перекладення творів української та зарубіжної класики, оригінальні композиції для акордеона, обробки народного мелосу, сучасний модерн, авангард, естрадно-джазова музика. Вивчення композицій різних стилів і епох розширює музичний кругозір і сприяє вихованню художнього смаку студентів-акордеоністів.

Варто відзначити, що важливим завданням української баянно-акордеонної школи є підготовка не лише високопрофесійного фахівця, але й усебічно розвиненої особистості, здатної вільно орієнтуватися в інформаційно-культурному просторі, постійно самовдосконалюватися і розширювати горизонти й можливості власного пізнання і творчих здобутків.

Отже, баянно-акордеонне мистецтво в ході історичного розвитку ствердило методичну та виконавську функції як невід'ємні складові школотворення, яке відбувалося за участі видатних діячів баянноакордеонного мистецтва.

\section{Лimepamypa:}

1. Алексєєв І. Д. Викладання гри на баяні : навч. посіб. для консерваторій та муз. училищ : вид. 1-е. К., 1957. 144 с.

2. Арсенічева Т. О. Музичне виконавство як форма буття індивідуального духовного досвіду митця. Київське музикознавство: Культурологія та мистеитвознавство. К. : НМАУ, 2004. Вип. 13. С. 263-268.

3. Басурманов А. П. Справочник баяниста. 2-е изд. М. : Сов. композ., 1987. 424 с.

4. Давидов М. А. Історія виконавства на народних інструментах: Українська академічна школа : підручник [для вищих та серед. муз. навч. закладів]. К. : HМАУ, 2005. $418 \mathrm{c}$.

5. Давидов М. А. Київська академічна школа народно-інструментального мистецтва : посібник з курсу «Історія виконавства на народних інструментах» [для вищих муз. навч. закладів]. К. : НМАУ, 1998. 223 с. 
6. Падалка Г. М. Музичний смак учителя та його виховання. Музика в школі. 1972. № 1. C. 47-59.

7. Семешко А. А. Композитор - баяніст - художник. Україна музична. К. : ФАДА ЛТД, 1998. С. 20-21.

\section{References (transliterated and translated):}

1. Alekseiev I. D. Vykladannia hry na baiani: navchalnyi posibnyk dlia konservatorii ta muzychnykh uchylyshch (Teaching how to play the accordion : Tutorial for conservatoires and music schools). $1^{\text {st }}$ ed. Kyiv, 1957, 144 p. (in Ukrainian).

2. Arsenicheva T. O. Muzychne vykonavstvo iak forma buttia indyvidualnoho dukhovnoho dosvidu mytsia (Music performance as an infinite being form of master's individual cultural proficiency). Kyiivske muzykoznavstvo: Kulturolohiia ta mystetstvoznavstvo (Kyiv Music Studies: Culture and Art Studies). Kyiv, NMAU (National Music Academy of Ukraine), 2004. Issue 13. P. 263-268. (in Ukrainian).

3. Basurmanov A. P. Spravochnik baianista (Accordionist's guide). $2^{\text {nd }}$ ed. Moscow : Sovietskiy Kompozitor (Soviet Composer), 1987. 424 p. (in Russian).

4. Davydov M. A. Istoriia vykonavstva na narodnykh instrumentakh: Ukraiinska akademichna shkola: pidruchnyk [dlia vyshchykh I serednikh muzychnykh navchalnykh zakladiv] (History of folk instruments performance: Ukrainian academic school : Course book [for higher and intermediate music institutions]). Kyiv, NMAU (National Music Academy of Ukraine), 2005. 418 p. (in Ukrainian).

5. Davydov M. A. Kyiivska akademichna shkola narodno-instrumentalnoho mystetstva: posibnyk z kursu «Istoriia vykonavstva na narodnykh instrumentakh» [dlia vyshchykh muzychnykh navchalnykh zakladiv] (Kyiv academic school for folk and instrumental art mastery: Textbook for course The history of folk instruments performance [for higher music institutions]). Kyiv, NMAU (National Music Academy of Ukraine), 1998. 223 p. (in Ukrainian).

6. Padalka H. M. Muzychnyi smak uchytelia ta ioho vykhovannia (Teacher's music taste and its cultivation). Muzyka v shkole (Music at School). 1972. No 1. P. 4759. (in Ukrainian).

7. Semeshko A. A. Kompozytor - baianist - khudozhnyk (Composer -accordionist master). Ukraiina muzychna (Ukraine Musical). Kyiv : FADA LTD, 1998. P. 20 21. (in Ukrainian).

Стаття надійшла до редакції 02.12.2018

\section{Деякі аспекти школотворчої функції баянно-акордеонного мистецтва}

У статті розглядається проблема розвитку сучасного баянноакордеонного мистецтва крізь призму школотворчої функції баянноакордеонного мистецтва. Процес формування українського музичного мистецтва тісно пов'язаний з історичними та соціокультурними передумовами, які увібрали традиції вітчизняної та західноєвропейської музичних культур. 3 цієї точки зору значний інтерес викликає баянно- 
акордеонне мистецтво в Україні, в якому віддзеркалено музичноісторичні тенденції розвитку: академічного, народно-інструментального виконавства. Автор робить висновок, що важливим завданням української баянно-акордеонної школи є підготовка не лише високопрофесійного фахівця, але й всебічно розвиненої особистості, здатної вільно орієнтуватися в інформаційно-культурному просторі, постійно самовдосконалюватися і розширювати горизонти й можливості власного пізнання та творчих здобутків. Баянно-акордеонне мистецтво в ході історичного розвитку ствердило методичну та виконавську функції як невід'ємні складові школотворення, яке відбувалося за участі видатних діячів баянноакордеонного мистецтва.

Ключові слова: баянно-акордеонна школа України, методика викладання у вищих навчальних закладах.

\section{A. Yevtushenko}

\section{Some Aspects of School-making Function of Bayan-accordion Art}

The article deals with the problem of bayan (button accordion) and accordion art mastery through its school-making function. The process of shaping Ukrainian musical art mastery is closely related to historical and socio-cultural preconditions that absorbed the traditions of national and West-European music cultures. Viewed in this way, substantial interest is being aroused by Ukrainian bayan and accordion art mastery that reflects its music and historical development tendencies as academic, folk and instrumental performance. The important target of Ukrainian bayan and accordion school is to train not only highly professional experts but also many-sided personalities. The author concludes that the important task of the Ukrainian bayan-accordion school is to prepare not only a highly professional specialist, but also a fully developed personality, able to freely navigate the information and cultural space, constantly improve themselves and expand the horizons and possibilities of their own cognition and creative achievements. Bayan-accordion art during the historical development confirmed the theoretical and performing functions as an integral part of school formation, which took place with the participation of prominent figures of bayan-accordion art.

Key words: Ukrainian bayan (button accordion) and accordion school; teaching methods in higher educational institutions.

Рецензент - кандидат педагогічних наук, доцент Р. В. Ваврик 